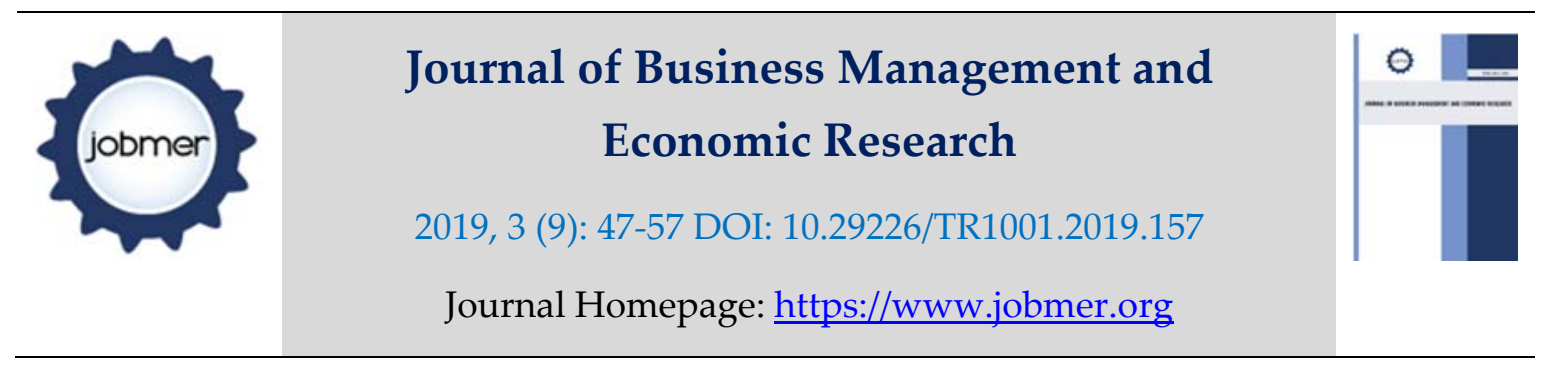

\title{
Effect of Entrepreneur Innovativeness on Financial Inclusion among Women Owned Enterprises in Kenya
}

\author{
Judith Nguli \\ Moi University \\ ngulijudith2@gmail.com
}

\begin{abstract}
The main purpose of the study was to determine the effect of entrepreneur innovativeness on financial inclusion among women operated enterprise. The study used positivism approach in explanatory design. Using a survey of 723 women owned enterprises the study used multiple regression framework to test the hypotheses that entrepreneur innovativeness does not have effect on financial inclusion. The variable proxies were obtained from literature review and indices were constructed to measure them. Findings showed that entrepreneur innovativeness emerged as a strong predictor of financial inclusion of women operated enterprises in rural areas. Specifically, the analysis revealed that female entrepreneurs who are innovative are more likely to be financially included. Based on the findings, adopting modern financial technologies such as Mpesa, agency banking, credit cards are more likely to improve financial inclusions among women owned enterprises. Therefore, the study has attempted to contribute to financial innovation theory building through establishment of relationship innovation and financial inclusion. The main contribution of the study was on establishing the pivotal role of entrepreneur innovation as an enabler of financial inclusion. In addition, policy recommendations and areas for further study by finance scholars have been suggested.
\end{abstract}

Keywords: Entrepreneur Innovativeness, Financial Inclusion, Women Owned Enterprise

\section{Introduction}

Financial inclusion can be defined as provision and access of financial services by marginalized group such as rural population and people with disabilities at an affordable cost. According to World Bank report (2014) current reforms and development in most sub-Saharan Africa countries have given much attention in financial inclusion (World Bank, 2014). Globally, financial inclusion is on the rise as an important policy 
tool in achieving sustainable Development Goals (SDGs) (Klapper \& Hess, 2018). As such, policy makers have heightened interest in in enhancing financial inclusion. The Findex 2017 data shows 1.2 billion adults have obtained an account since 2011 representing about $69 \%$ of world adults as financially included (World Bank, 2018). In developing economies, the number of included persons has increased 54 percent to 63 percent.

However, women, particularly in developing economies have continuously registered low financial inclusion rates than men with the most recent statistics showing 9 percentage points gap in favor of men than women (United Nations, 2015). In recent randomized experiments shows female operated enterprises, in comparison with the male counterparts underperformed in terms of turnover, growth or survival prospects as results of lack of operating finances (Berge et al. 2013); It is noted that financial exclusion of female entrepreneurs has impeded the growth of their enterprises, rendering them non-participants to the modern market economy (Reyes 2013). Further, they are unable to take advantage of business opportunities or counter weather systemic or idiosyncratic shocks to their enterprises (Demirgu" $\mathrm{c}_{s}$-Kunt et al. 2008). Research by Mertinez (2013) indicates the use of informal finances were rampant among women.

Thus, emphasizing on financial inclusion among women is paramount in reducing poverty as well as economic growth. Hence, delivering affordable and effective financial services for saving money, borrowing money and making payment among rural women especially for women owning small business is important for in their welfare and reducing poverty ( (United Nations, 2015). However, the path to greater women's financial inclusion is dependent upon the creation of a more innovative financial system that addresses the barriers such as lack of collateral, distance to formal financial institutions in accessing affordable financial services (Lauer and Lyman, 2015).

Therefore, to ensure women are finically included it is important to find approaches that can harness the untapped potential of women owned businesses that according to world bank are excluded from the formal financial sector or not fully served by financial products and services (world Bank, 2017). Such approaches can enable segments of the population to develop their own capacities, strengthen their human and physical capital, carry out various income-generating activities and manage the risks associated with their livelihoods. Thus, this study looked at entrepreneur innovative as an approach which can enhance financial inclusion among women entrepreneurs.

Financial innovation has marked impact on the emancipation of women in societies that have tended to be highly patriarchal. The use of new technology and innovative business models to improve the supply and 
outreach of financial services, and improved financial literacy and capacity by users appear among the most prominent avenues for improved financial inclusion among women entrepreneurs (UNCTAD, 2012). Innovative business models and services have emerged and expanded addressing traditional barriers to access to financial services, both on a for-profit and non-profit basis, and have created new business opportunities.

Technology has gradually improved the provision of financial services in the past, such as credit cards, debit cards, prepaid cards and ATMs. Exponential progress in information and communications technologies has opened the way for new financial services and business models exhibiting a significant potential for financial inclusion (Peterson, 2018). New mobile banking and payment technologies have given rise to technology-based business models that can broaden access to basic financial services through a greater use of correspondent banks (representatives of a bank carrying out transactions on behalf of banks) using existing networks of agents and institutions, such as post offices, supermarkets, grocery shops, convenience stores, gas stations and lottery outlets (Haider, 2018). They offer only elementary transaction services or a broader range of financial services which has had a substantial impact on financial inclusion.

Despite significant improvements in the financial sector's viability, profitability and competitiveness, there are significant concerns that banks have failed to provide basic banking services to a significant segment of the population, especially from among women entrepreneurs (world Bank, 2016). Thus, governments are coming up with strategies to improve financial inclusion that can lift the standard of living of the poor and the disadvantaged (Commonwealth Secretariat, 2014). While there is a growing body of evidence surrounding the impact of innovation on financial inclusion, there remains much to learn about the ways in which innovation among women entrepreneurs can contribute to women's financial inclusion. This study therefore attempted to found put how various technology innovations in financial service overcome some of these barriers to women's financial inclusion.

\section{Literature Review (Hypothesis Development)}

According to Lauer and Lyman (2015) financial inclusion can be influenced by financial innovations services such as technological policy. Lauer and Lyman (2018) refer to innovations in the financial services as digital access to utilize modern financial services. An increasing number of financial services such as insurance, credit, remittances, payments and savings can be retrieved and conveyed through digital channels where value is kept and conducted in modern technology with no paperwork involved or 
physical presence which can enhance financial inclusion. Online financial services not limited to mobile wallets, mobile banking and mobile money transfers are a key element of automated financial services.

As per Singh (2017) high-tech creations are able to withstand geographical barriers, minimize operational costs that come with financial services and encourage openness in so doing cultivate trust within financial systems. By influencing acquisition and accumulation of financial info, modern technology programs can aid in reducing the imbalances between lenders and borrowers that keep huge parts of the poor demography deprived access to financial systems. They can also re-adjust financial independence and privacy for customers and possibly lessen contingencies involving assimilation and seizure of these funds by others.

Regardless of considerable venture capital within online forums and some renowned successes automating transfers and payments, women are more apt to experience challenges when it comes to accessing and interacting with hi-tech financial services. As creative financial services basically depend on telecommunication networks, access to mobile computerization and the freedom to use it whenever desired, are critical factors in establishing digital financial inclusion.

According to GSMA (2015), women have a 14 percent probability of not owning a mobile phone as compared to men. The gender difference is bigger in specific areas around the globe. An example of South Asia where phone ownership among women is unlikely to an estimate of 38 percent. Rowntree (2019) states that the gender gap is minimal in Sub-Saharan Africa, however, this varies regionally, specifically between East Africa, which records high rates of mobile phone ownership for both genders, and states such as Democratic Republic of Congo and Niger, where the number of women owning mobile phones lies at a percentage of 45 and 33 percentage lower than that of men, respectively. A small number of women owning mobile phones translates to fewer women being able to sign up for online financial accounts in their names, subsequently hindering them from fully acquiring certain modernized financial services, for instance, attaining credit, making or receiving money transfers, paying bills and determining the usage.

The worldwide shift in telecommunications and transformations in modernized payment systems has created new ways of ensuring the needy access to low-cost and dependable financial services and products. The current gender inequalities in financial inclusion can be reduced by these creative forums, in turn altering both the demand and supply variables that are behind women's present day bar from financial systems. The World Bank (2018) attests that Modern technology services can also supersize some of the advantages of financial inclusion for women through conventional channels. 
Journal of Business Management and Economic Research (JOBMER), vol.3, issue.9, pp.47-57

As deduced by the World Bank (2018), throughout the past ten years, financial hi-tech innovations have grown popular in the financial inclusion sector and are accredited among institutions like the World Bank, GSMA, BMGF and CGAP as an inexpensive solution for banking the less fortunate. These mediums have shown favorable odds in withstanding some of the gender-based setbacks with regards to usage and access. New findings also speculate endless optimistic results related to innovation and financial inclusion of women that seem to resolve certain impediments brought by conventional financial inclusion methods. Based on Klapper and Hess (2016), gender-specific hindrances to women's complete financial inclusion still exist bearing an effect on innovation systems thus explaining the relentless gender gaps despite the growing innovation. Financial knowledge among women and access to mobile technology are examples of such impediments. Ashraf (2009), Jakiela and Ozier (2016) claim that there may be issues regarding confidentiality and clarity causing modernized payments to be less safe and at risk of misappropriation by family members for women. Allen et al. (2016) further explains that there also exists possible restrictions with liquidating, that is, their ability to gain entry to kiosks and old fashioned establishments independently without guidance, more specifically when doing so depends on women's considerable higher levels of movement. Thus, this study hypothesized that:

H1: High entrepreneur innovations improves financial inclusion among women owned enterprises

\section{Methodology}

The study employed explanatory research design in positivism approach. Data was collected using seven point Likert scale $(1=$ strongly disagree to $7=$ strongly agree $)$ questionnaires from a randomly selected sample size of 723 women owned enterprises drawn from target population of 8000 women owned enterprise in North Rift Region Economic Bloc Counties. The choice of women owned enterprises was bound by the fact that the respondents hailed from developing economies and culturally women were not allowed to own assets and bank accounts. Consequently, their levels of financial exclusion are higher. Moreover, financial access by SMEs have myriad of hurdles which are due to inability of them to be managed professionally and lack of requisite financial management skills thus they rarely have reliable books of accounts for ease of loan evaluation.

\subsection{Reliability and validity of measurement of variables}

Financial inclusion scale was adopted form the Word Bank (2012) scale and entrepreneurial innovativeness scale was adopted from Goldsmith et al., (1995). ALL item instrument was developed on a seven-point 
likert scale of $1-7(1=$ strongly disagree to $7=$ strongly agree $) ..$ Cronbach's alpha was used to determine reliability, where Cronbach's coefficient, having a value of more than 0.6 is considered adequate for such explanatory work (Hair et al., 2010). Exploratory factors analysis (EFA) was carried out to establish construct, convergent, discriminant validity. All the reliability index values are greater than 0.7 indicating that the level of internal consistency is acceptable. Evidently, the present study results as outlined in Table 1 below demonstrates that all variables had a Cronbach alpha of more than .70 thus stability and consistency of measurement was upheld. Thus, the results met the required threshold for further analysis as documented in the subsequent sections of this thesis document.

The Exploratory Factor Analysis (EFA) showed that Eigen values were above the accepted value of 1 (Hair et. al. 2014; Yong \& Pearce, 2013) and cumulative extracted variance above 50\% Thus, all the items were considered appropriate to explain the variable. Moreover, from the Table 1 below, Bartlett's Test of Sphericity produced a significant Chi-Square $\left(\chi^{2}\right)$ and Kaiser - Meyer - Olkin measure of sampling adequacy above the acceptable value of .50 (Field, 2005), showing that it was appropriate to subject the data on financial inclusion to factor analysis (Leech et al., 2013).

Table 1. Reliability and validity of measurement of variables

\begin{tabular}{|c|c|c|c|c|c|}
\hline & loadings & KMO & $\% \mathrm{CV}$ & AVE & CR \\
\hline $\begin{array}{l}\text { financial inclusions(Bartlett's Test of Sphericity }=6405.45^{* *}, 1 \\
\text { Values }=11.101 \text { ) }\end{array}$ & iigen & 0.83 & 72.67 & 0.52 & 0.77 \\
\hline We save our money in mobile money platform & 0.57 & & & & \\
\hline We borrow money using money mobile system, M-Mshwari & 0.63 & & & & \\
\hline We transact our bank accounts using mobile phones & 0.58 & & & & \\
\hline We pay insurance premium using mobile phones & 0.56 & & & & \\
\hline We commonly use Mobile Financial services & 0.54 & & & & \\
\hline We pay most of our bills through the Mobile financial services & 0.54 & & & & \\
\hline We encourage clients to pay for services via the mobile phone & 0.62 & & & & \\
\hline Mobile Financial Inclusion & 0.58 & & & & \\
\hline I often save business money in the bank account & 0.54 & & & & \\
\hline $\begin{array}{l}\text { I frequently receive debtors payments by cheques or bank } \\
\text { transfer }\end{array}$ & 0.51 & & & & \\
\hline I frequently pay my suppliers through cheques or bank transfer & 0.52 & & & & \\
\hline I often borrow loans from the bank to finance my business & 0.59 & & & & \\
\hline $\begin{array}{l}\text { I prefer borrowing from informal sources such family and } \\
\text { friends than the bank }\end{array}$ & 0.56 & & & & \\
\hline 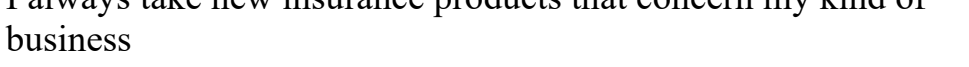 & 0.52 & & & & \\
\hline
\end{tabular}


There is usable access road leading to the nearest formal financial institutions 0.56

The nearest bank is less than 5KM from home $\quad 0.57$

I Live within $1 \mathrm{KM}$ of an ATM that I can easily access my

account $\quad 0.53$

I know which documents which are required to open a bank
account

I receive prompt information regarding my transactions $\quad 0.60$

Traditional Financial Inclusion $\quad 0.58$

Entrepreneur innovations(Bartlett's Test of Sphericity $=118.242 * *$, Eigen Values $=5.601$ )

$\begin{array}{llll}0.87 & 75.28 & 0.57 & 0.89\end{array}$

We are eager to adopt new way of doing things in our firm $\quad 0.79$

We are always among the first to accept something new in the $\quad 0.63$

industry

0.56

compared to our competitors $\quad 0.56$

If we heard new products and services we would adopt them $\quad 0.87$

We would adopt an innovation, even if I have not heard of it $\quad 0.90$

Our firm would always seek out new ways of doing things $\quad 0.89$

*We perceive innovative as risky $\quad 0.74$

\subsection{Analytic Model of analysis}

Quantitative techniques for information investigation was utilized with both elucidating and inferential insights (recurrence means and standard deviations) being connected to clarify every target of the study. This study tested the validity of the multiple regression models utilizing ANOVA, F-dissemination and Ttest. ANOVA is likewise the information examination strategy that is utilized to decide if there are critical contrasts between at least two gatherings or tests at a chosen likelihood level (Mugenda and Mugenda, 2003). To test the essentialness of regression coefficient, $t$ test was performed. The study received an essentialness level of 0.05 . The p esteem acquired was the deciphered dependent on the level of criticalness. The investigation dismissed the invalid theory if the p-esteem was be under 0.05 for the elective speculation. In the event that the p-esteem was more prominent than the level of noteworthiness the study won't dismiss the invalid theory. At long last Multiple Linear Regression model was utilized to build up the hugeness of the straight relationship free factors on the reliant variable. The multiple regression model was be;

$Y=\beta_{0}+\beta_{1} X_{1}+\varepsilon$ ...Model 1

Where: 
$\mathrm{Y}=$ Financial inclusion.

$\mathrm{X}_{1}=$ entrepreneur innovation

$\varepsilon=$ error term

$\beta_{0}$-constant (Y- intercept)

$\beta \mathrm{i}$ - are the regression coefficients of each $\mathrm{Xi}(\mathrm{i}=1)$

\section{Results}

Descriptive statistics of the response variable under this section is financial inclusion, which was the dependent variable of the study. Findings from Table 2 showed that there was high level of financial inclusion $($ Mean $=4.57, \mathrm{SD}=1.26)$ and innovation among women entrepreneurs $(\mathrm{Mean}=4.90, \mathrm{SD}=1.22)$. From this we can presume that with high innovation there is high financial inclusions, this assumption have been partly proofed by correlation results which showed that There is positive and significant relationship between entrepreneur innovation and financial inclusions ( $\mathrm{r}=.594)$.

Table 2. Descriptive and Correlation results

\begin{tabular}{|c|c|c|c|c|c|c|c|c|c|}
\hline & Mean & $\begin{array}{c}\text { Std. } \\
\text { Deviation }\end{array}$ & Skewness & 1 & 2 & 3 & 4 & 5 & 6 \\
\hline 1 & 4.57 & 1.26 & -0.32 & 1 & & & & & \\
\hline 2 & 4.90 & 1.22 & -0.58 & $.594 * *$ & 1 & & & & \\
\hline 3 & 4.81 & 1.29 & -0.25 & $.412 * *$ & $.437 * *$ & 1 & & & \\
\hline 4 & 3.27 & 1.61 & 0.16 & -0.038 & -0.065 & -0.025 & 1 & & \\
\hline 5 & 4.62 & 1.81 & -0.35 & 0.052 & 0.062 & 0.003 & $.117 * *$ & 1 & \\
\hline 6 & 1.28 & 0.66 & 2.67 & $.083 *$ & 0.016 & $.104 * *$ & 0.03 & $-.131 * *$ & 1 \\
\hline \multicolumn{10}{|c|}{ ** Correlation is significant at the 0.01 level (2-tailed). } \\
\hline \multicolumn{10}{|c|}{${ }^{*}$ Correlation is significant at the 0.05 level (2-tailed). } \\
\hline & $1=$ & \multicolumn{8}{|c|}{ financial Inclusion } \\
\hline & $2=$ & \multicolumn{8}{|c|}{ entrepreneur innovation } \\
\hline & $3=$ & \multicolumn{8}{|c|}{ firm performance } \\
\hline & $4=$ & \multicolumn{8}{|c|}{ firm age } \\
\hline & $5=$ & \multicolumn{8}{|c|}{ industry type } \\
\hline & $6=$ & \multicolumn{8}{|c|}{ firm size } \\
\hline
\end{tabular}

\subsection{Test of hypotheses}


Regression is one of the pertinent and commonly used statistical method in research. It provides a platform for which causal-effect relationships among variables of interest in the study are examined. Findings showed that the $\mathrm{R}^{2}$ value $=0.385$ which shows that the model parameters account for $38,5 \%$ in the change of financial inclusion is explained by entrepreneur innovations. The analysis of variance attributed to the model parameters is significant as indicated by the F-ratio $=78.64$ with a $p$-value $=0.000$ which implies that the variation accounted for by the model parameters on financial inclusions is significant.

Hypothesis $\left(\mathrm{H}_{1}\right)$ postulated that high entrepreneur innovations improve financial inclusion among women owned enterprises. Findings showed that entrepreneur innovations had positive and significant effect on financial inclusions among women owned enterprises $(\beta=0.53$ ( $\mathrm{p}$-value $=0.000$ which is less than $\alpha=0.05$ ) implying that the hypothesis was accepted and it was concluded that entrepreneur innovations increase financial inclusion. These findings were supported by Singh (2017) who argued that Technological innovation improves financial inclusions among women by overcoming tradition barriers for women access to financial services (Singh, 2017). Similarly, World Bank report (2018) showed that financial inclusions services can also magnify some of the benefits of financial inclusion for women through traditional platforms. Financial technological innovations have increasingly been championed by many in the field of financial inclusion.

Table 3: Regression Results

\begin{tabular}{lccccc}
\hline & \multicolumn{2}{c}{ Unstandardized } & \multicolumn{3}{c}{ Standardized Coefficients } \\
& B & Std. Error & Beta & t & Sig. \\
\hline (Constant) & 0.91 & 0.23 & & 3.92 & 0.00 \\
entrepreneur innovations & 0.53 & 0.04 & 0.51 & 14.61 & 0.00 \\
Firm performance & 0.18 & 0.03 & 0.18 & 5.21 & 0.00 \\
firm age & 0.00 & 0.03 & -0.01 & -0.16 & 0.87 \\
industry type & 0.02 & 0.02 & 0.03 & 0.90 & 0.37 \\
firm size & 0.11 & 0.06 & 0.06 & 1.87 & 0.06 \\
Model summary statistics & & & & & \\
R & 0.621 & & & & \\
R Square & 0.385 & & & & \\
Adjusted R Square & 0.380 & & & & \\
Std. Error of the Estimate & 0.989 & & & & \\
Model Fitness & & & & & \\
F & 78.64 & & & & \\
Sig. & .000 & & & & \\
\hline
\end{tabular}


a Dependent Variable: FI

\section{Conclusion and Recommendation}

The study concludes that financial innovations such agent banking, Mpesa, electronic banking among others enhances financial inclusions among women especially in rural areas. The study recommends that financial institutions should focus more on offering banking services through mobile money platforms. The services should not be limited to linking existing accounts to the mobile money but should also include opening bank accounts using mobile money platform. To achieve this, the study recommends those mobile money service providers, financial institutions and the government work closely in ensuring security of the mobile money platforms through enacting the relevant legislations. The study recommends that the government should develop and support initiatives which enhance responsible financial innovations. This will help break away from the traditional banking system as the only way of accessing financial services

\section{References}

Allen, F., Demirgüç-Kunt, A., Klapper, L., \& Martinez Peria, M. S. (2016). The Foundations of Financial Inclusion: Understanding Ownership and Use of Formal Accounts. Journal of Financial Intermediation, 27, 1-30

Ashraf, N. (2009). Spousal Control and Intra-Household Decision Making: An Experimental Study in the Philippines. American Economic Review, 99(4), 1245-1277.

Commonwealth Secretariat. 2013. 'Savings and Credit Organizations Owned or Managed by Women: What makes them successful and what strategies do they use? Lessons from India.' Marlborough House, London.

Demirgüç-Kunt, A., Klapper, L. F., Singer, D., \& Van Oudheusden, P. (2015). The Global Findex Database 2014: Measuring Financial Inclusion Around the World (World Bank Policy Research Working Paper 7255).Washington, DC: World Bank

Field, A. (2005) Reliability analysis. In Field, A., Ed., Discovering Statistics Using spss. 2nd Edition, Sage, London, Chapter 15.

Goldsmith, R. E., J.B. Freiden, and J.K. Eastman. 1995. The Generality/Specificity Issue in Consumer Innovativeness Research. Technovation. 15(10): 601-611.

GSMA. (2015). Women and Mobile Money: Insights from Kenya (Rep.). London: GSM Association

Haider, H. (2018). "Innovative financial technologies to support livelihoods and economic outcomes", . K4D Helpdesk Report. Brighton, UK: Institute of Development Studies

Hair, J., Black, W., Babin, B., Anderson, R., \& Tatham, R. (2014). Multivariate data analysis (6th ed.). NJ: Pearson Prentice Hall. 
Journal of Business Management and Economic Research (JOBMER), vol.3, issue.9, pp.47-57

Hair, J.F., Black, W.C., Babin, B.J., \& Anderson, R.E. (2010). Multivariate Data Analysis. Seventh Edition. Prentice Hall, Upper Saddle River, New Jersey.

Jakiela, P., \& Ozier, O. (2016). Does Africa Need a Rotten Kin Theorem? Experimental Evidence from Village Economies. The Review of Economic Studies 83(1), 231-268.

Klapper, L., \& Hess, J. (2016). Financial Inclusion and Women's Economic Empowerment: A Briefing for the UN

Lauer, K., \& Lyman, T. (2015, March 10). Digital Financial Inclusion. Retrieved August 11, 2017, from http://www.cgap.org/publications/digital-financial-inclusion.

Leech, N., Barrett, K.C. and Morgan, G.A. (2013). SPSS for intermediate statistics: Use and interpretation. (2nd ed.). London: Lawrence Erlbaum Associates.

Mugenda, O. M. \& Mugenda, A. G. (2003). Research methods: Quantitative and qualitative Approaches. Nairobi: African Centre for Technology Studies.

Peterson K Ozili (2018), "Impact of Digital Finance on Financial Inclusion and Stability",!MPRA Paper No. 84771, posted 24 February 2018 10:08 UTC Online at https://mpra.ub.uni-muenchen.de/84771/ 2

Rowntree, “The Mobile Gender Gap Report 2019." Secretary-General's High-Level Panel on Women's Economic Empowerment (Rep.). New York, NY: Secretariat, UN Secretary-General's High-Level Panel on Women's Economic Empowerment

Singh, S 2017, 'Financial inclusion as practice: microfinance and mobile money' in Paul Battersby and Ravi K. Roy (ed.) International Development: A Global Perspective on Theory and Practice, Sage, Los Angeles, United States, pp. 230-244.

The World's Women 2015: Trends and Statistics. New York: United Nations, Department of Economic and Social Affairs, Statistics Division. http://unstats.un.org/unsd/gender/worldswomen.html

UNCTAD, 2012, Mobile Money for Business Development in the East African Community: A Comparative Study of Existing Platforms and Regulations (Geneva, United Nations publication).

United Nations, Sustainable Development Goals, 2015a http://www.un.org/sustainabledevelopment/ gender-equality/\#751f89fa361630f60v

World Bank. (2014). Global Financial Development Report 2014: Financial Inclusion (Rep.). Washington, DC: World Bank

World Bank. (2016). Women, Business and the Law 2016: Getting to Equal (Rep.). Washington, DC: World Bank.

World Bank. 2012. 'Gender Equality and Development.' World Development Report, Washington D. C., USA

World Bank. 2018. "From Spreadsheets to Suptech: Technology Solutions for Market Conduct Supervision." http://documents.worldbank.org/curated/en/612021529953613035/pdf/127577REVISED-Suptech-Technology-Solutions-for-Market-Conduct-Supervision.pdf

Yong, A.G. \& Pearce, S. (2013) A beginner's guide to factor analysis: Focusing on exploratory factor analysis. Tutorials in Quantitative Methods for Psychology, 9(2), 79-94. doi: 10.20982/tqmp.09.2.p079 